\title{
EFEKTIFITAS PELAYANAN PUBLIK PENERBITAN IZIN USAHA DI KOTA BAUBAU
}

\author{
Farid Yusuf Nur Achmad \\ Program Studi Ilmu Pemerintahan, Fakultas Ilmu Sosial dan Ilmu Politik, \\ Universitas Muhammadiyah Buton, Jl. Betoambari No. 36 Baubau. \\ E-mail: faridyusufnurachmadumb@gmail.com
}

\begin{abstract}
This study aims to determine how the effectiveness of publishing services business license in Licensing Service Agency and Investment Baubau city as well as to determine the factors that hinder the effectiveness of publishing services business license in Licensing Service Agency and Investment Baubau City. Study is a qualitative descriptive study, the research done by examining primary and secondary data. The population in this research that all employees at the Agency for Investment and Licensing Services Baubau city as many as 33 people. The sampling technique using total sampling. Data collection techniques are: observation, interviews, literature study and documentation. Processing and presentation of data by using data reduction, data presentation and verification of data. Data sources are: Primary and Secondary, Technical Analysis used in this research is qualitative descriptive analysis. Results of the study are: publishing services business license in Licensing Service Agency and Investment Baubau city is said to be effective, the factors that hinder the effectiveness of publishing services business license Licensing Service Agency and Investment Kota Baubau namely: the factor of time, cost factor and requirements in the licensing service, In an effort to streamline the process of licensing services to the public the government is expected to further the transparency of financial reasons that one way to do expose the online and offline media. In the matter raising public awareness as users of government services shall direct socialization in employerslocal businessmen in an effort to take advantage of local entrepreneurs. Penginkatan performance and resource officers, the government in this case the service provider must also accept criticism and suggestions from users are a good and wise.
\end{abstract}

\section{Keywords: Public service, Policy}




\section{A. PENDAHULUAN}

Pelayanan publik yang berkualitas menjadi salah satu tolok ukur untuk melihat apakah disuatu organisasi pemerintah (sektor publik) telah terjadi reformasi birokrasi. Masih banyaknya kesan miring yangmuncul atas pelayanan publik yang dilakukan oleh sector publik, tidak terlepas dari kenyataan bahwa rendahnya kualitas pelayanan public yang diberikan kepada masyarakat sebagai konsumen. Rendahnya pelayanan public dimaksud, antara lain ditandai dengan beberapa ciri. Pertama, tidak transparannya biaya dalam pengurusan perizinan; kedua, berbelit-belitnya pelayanan bahkan tidak jarang membuat masyarakat menjadi frustasi dan ketiga, waktu pelayanan yang tidak jelas, sehingga masyarakat tidak dapat memprediksi kapan selesainya. Kurniawan, Agung, (2005:60).

Good Governance merupakan proses penyelenggaraan birokrasi dalam pelayanan barang dan jasa public (public goods and services) yang dalam pelaksanaannya harus senantiasa berpegang pada prinsip-prinsip good governance, yaitu : prinsip efektifitas (effectiveness), keadilan (equity), partisipasi (participation), akuntabilitas (accountability) dan transparansi (transparency) Gaspersz,V, (1997 : 34).

Tuntutan masyarakat untuk mendapatkan pelayanan yang berkualitas terus meningkat dari waktu ke waktu. Di dalam perkembangannya, pelaksanaan pembangunan di Kota Baubau seringkali mengalami banyak hambatan. Adanya krisis seperti krisis ekonomi, sosial, budaya, dan kepercayaan terhadap kinerja pemerintahan mengakibatkan semakin lesunya bidang pembangunan, termasuk juga pembangunan di bidang ekonomi Kansil, (2005 : 70).

Adanya kondisi dunia usaha yang tidak menentu tersebut, menimbulkan ketimpangan di dalam pembangunan perekonomian. Tantangan yang dihadapi dalam pelayanan public bukan hanya menciptakan sebuah pelayanan yang efisien, tetapi bagaimana pelayanan juga dapat dilakukan dengan tanpa membeda-bedakan status dari masyarakat yang dilayani. Dengan kata lain, bagaimana menciptakan pelayanan yang adil dan demokratis.

Pelayanan merupakan tugas utama yang hakiki dari sosok aparatur, sebagai abdi negara dan abdi masyarakat. Tugas ini telah jelas digariskan dalam pembukaan UUD 1945 alinea keempat, yang meliputi empat aspek pelayanan pokok aparatur terhadap masyarakat, yaitu melindungi segenap bangsa Indonesia dan seluruh tumpah darah Indonesia, memajukan kesejahteraan umum, mencerdaskan kehidupan bangsa dan melaksanakan ketertiban dunia yang berdasarkan kemerdekaan, perdamaian abadi dan keadilan sosial. Dan diperjelas lagi dalam Keputusan Menteri Pemberdayagunaan Aparatur Negara No. 63 tahun 2003 tentang Pedoman Umum Penyelenggaraan Pelayanan Publik yang menguraikan pedoman umum penyelenggaraan pelayanan public Kurniawan, Agung, (2005 : 79). 
Sejak dikeluarkannya Peraturan Daerah Kota Baubau No. 23 Tahun 2003 tentang Retribusi Izin Industri, Perdagangan dan Pergudangan, Pemerintah Kota Baubau sesuai dengan peraturan Menteri Perdagangan Nomor : 36 / M-DAG / PER / 9 / 2007 tentang Penerbitan Surat Izin Usaha Perdagangan sebagaimana telah diubah dengan Peraturan Menteri Perdagangan Nomor : 39 / M-DAG / PER / 12 / 2011.

Kota Baubau merupakan salah satu kota yang sedang giat melakukan pembangunan di segala bidang. Sektor perekonomian merupakan focus utama di dalam mewujudkan kesejahteraan masyarakat Baubau. Hal ini terlihat, bahwa sekarang ini Kota Baubau dianggap sebagai kota industri dan perdagangan, kota transit, dan kota budaya. Tidak hanya sebagai kota yang berkembang, Reformasi birokrasi dijalankan dalam mewujudkan efektifitas kinerja aparat, biaya murah, hemat waktu, proses cepat dan mudah, efisien tenaga di dalam memberikan pelayanan kepada masyarakat, serta kepada sector swasta yang bergerak dalam usaha industry dan perdagangan. Tentunya hal ini didukung oleh kinerja Badan Pelayanan Perizinan dan Penanaman Modal Kota Baubau yang sangat baik dalam memberikan pelayanan kepada masyarakat.

Untuk mendukung upaya peningkatan pelayanan publik, sesuai visi dan misi jangka menengah Pemkot tahun 2013-2018, serta pelaksanaan UU No. 25 Tahun 2009 tentang Pelayanan Publik dengan petunjuk pelaksanaan yang termuat dalam Peraturan
Pemerintah No. 96 Tahun 2012, pelayanan publik dilakukan secara terpadu melalui Pelayanan Terpadu Satu Pintu (PTSP) berdasarkan instruksi Walikota Baubau No. 128 Tahun 2013 tentang Pembebasan Biaya atau Retribusi Pelayanan Perizinan Surat Izin Usaha Perdagangan SIUP, tahun 2015 Badan Perizinan Kota Baubau telah mengeluarkan 153 izin usaha.

Penelitian ini difokuskan pada, tata kelola Kantor Pelayanan Perizinan Terpadu yang dikelola oleh Badan Pelayanan Perizinan Kota Baubau dalam mereformasi birokrasi pelayanan publik agar dapat lancar, tertib, sederhana, proses cepat, murah, nyaman dalam public service dan kepuasan para pengusaha dalam proses pelayanan khususnya pendaftaran, hingga penerbitan surat izin usaha industry (IUI dan TDI). Serta faktor-faktor penghambat dan pendukung dalam proses reformasi birokrasi tersebut.

\section{B. METODE PENELITIAN}

Berdasarkan judul penelitian, jenis penelitian ini adalah kualitatif deskriptif - Populasi dalam penelitian ini yaitu seluruh pegawai pada Badan Pelayanan Perizinan dan Penanaman Modal Kota Baubau berjumlah 50 orang. Dari jumlah populasi tersebut ditentukan sampel sejumlah 30 orang, dalam penarikan sampel digunakan teknik penentuan sampel secara acak / purpose sampling, hal ini dilakukan sebagai upaya penulis untuk mendapatkan hasil yang maksimal.

Secara sederhana penelian ini memfokuskan pada dua variabel sebagai 
upaya memudahkan proses penelitian, yakni: Badan Pelayanan Perizinan dan Penanaman Modal Kota Baubau. Sebagai variabel terikat dengan maksud bahwa Pelayanan Perizinan adalah pemberian legalitas kepada seseorang atau pelaku usaha atau kegiatan tertentu, baik dalam bentuk izin maupun tanda daftar usaha. Dan Efektifitas Pelayanan Penerbitan Izin Usaha sebagai variabel bebas dengan maksud bahwa Efektifitas Pelayanan adalah suatu standar pengkuran untuk menggambarkan tingkat keberhasilan suatu organisasi dalam mencapai sasaran yang telah ditetapkan sebelumnya segala bentuk tindakan yang dilakukan oleh pemerintah kepada masyarakat yang bersifat legalitas atau melegalkan kepemilikan, hak, keberadaan, dankegiatan individu atau organisasi.

$\begin{array}{crr}\text { Setelah } & \text { data } & \text { dikumpulkan } \\ \text { melalui } & \text { proses } & \text { observasi, }\end{array}$
wawancara dan studi kepustakaan langkah selanjutnya adalah proses pengolahan data, reduksi data dalam penelitian ini yakni menjalankan analisis, menggolongkan, mengarahkan, membuang yang tidak perlu dan mengorganisasikan data sehingga kesimpulan akhirnya dapat diketahui.

Dengan menggunakan data primer dan sekunder yang tepat penelitian ini mengarah pada hasil yang maksimal.

\section{HASIL PENELITIAN}

1) Pelayanan Penerbitan Izin Usaha Pada Badan Pelayanan Perizinan Dan Penanaman Modal Kota Baubau.
Badan Pelayanan Perizinan dan Penanaman Modal Kota Baubau sudah sangat efektif dibandingkan daerah lain. Hal ini bahwa proses pelayanan yang dilakukan oleh BP3M sesuai dengan prosedur yang berlaku sudah efektif dengan parameter adalah tidak adanya keluhan masyarakat terhadap pelayanan yang diberikan. Dengan kondisi perekonomian yang sehat dan dinamis dapat meningkatkan minat masyarakat khususnya pengusaha untuk melakukan kegiatan usaha dibidang perekonomian. Sektor swasta yang bergerak dalam usaha industri dan perdagangan sangat berperan dalam memajukan perekonomian daerah.

Hal ini dapat dibuktikan dengan Kondisi perekonomian yang sehat dan dinamis dapat meningkatkan minat masyarakat kota Baubau khususnya pengusaha untuk melakukan kegiatan usaha di bidang perekonomian, sehingga dapat dikatakan efektif untuk itu Pelayanan public yang berkualitas menjadi salah satu tolok ukur untuk melihat apakah disuatu organisasi pemerintah (sektor publik) telah terjadi Reformasi Birokrasi serta berjalan efektif atau tidak.

Secara umumnya layanan dalam bentuk perbuatan dilakukan oleh petugas-petugas yang memiliki factor keahlian dan ketrampilan yang sesuai dibidangnya, hal ini disebabkan bahwa Tuntutan masyarakat untuk mendapatkan pelayanan yang berkualitas terus meningkat dari waktu ke waktu. Di dalam perkembangannya, pelaksanaan pembangunan di Kota Baubau seringkali mengalami banyak 
hambatan sehingga perlu adanya perbaikan dalam bentuk pelayanan. Tantangan yang dihadapi dalam pelayanan public di Kota Baubau bukan hanya menciptakan sebuah pelayanan yang efisien, tetapi bagaimana pelayanan juga dapat dilakukan dengan tanpa membeda-bedakan status dari masyarakat yang dilayani. Dengan kata lain, bagaimana menciptakan pelayanan yang adil dan demokratis sehingga pelayanan yang kami berikan dapat terus efisien. Disisi lain Pelayanan merupakan tugas utama yang hakiki dari sosok aparatur, sebagai abdi negara dan abdi masyarakat. Tugas ini telah jelas digariskan dalam pembukaan UUD 1945 dan menjadi tugas kita semua dalam mengektifkan setiap pelayanan yang ada dan menjadi tugas para pegawai sehingga terus menciptakan pelayanan yang efektif dan efisien. Dengan kata lain seluruh aparat harus bisa menjawab setiap keluhan masyarakat utamanya berhubungan dengan pelayanan yang efektif dan prima sesuai dengan tuntutan dari Reformasi Birokrasi.

Kata efektivitas tidak dapat disamakan dengan efisiensi, karena keduanya memilki arti yang berbeda walaupun dalam berbagai penggunaan kata efisiensi lekat dengan kata efektivitas. Efisiensi mengandung pengertian perbandingan antara biaya dan hasil, sedangkan efektivitas secara langsung dihubungkan dengan pencapaian tujuan. Efektivitasyaitu suatu keadaan yang mengandung pengertian mengenai terjadinya suatu akibat yang dikehendaki, efektif itu harus terkait dengan pencapaian tujuan dan sasaran suatu tugas dan pekerjaan dan terkait juga dengan kinerja dari proses pelaksanaan suatu pekerjaan. Disisi lain Efektivitas dapat dijadikan sebagai pengukuran dalam arti tercapainya sasaran atau tujuan yang ditentukan sebelumnya. Efektivitas ditinjau dari sudut pencapaian tujuan yang dimana keberhasilan suatu organisasi haruslah mempertimbangkan bukan hanya sasaran organisasi tetapi juga mekanisme mempertahankan diri dalam mengejar sasaran dengan kata lain, penilaian efektivitas harus berkaitan dengan masalah sasaran maupun tujuan dalam pelayanan Badan Pelayanan Perizinan dan Permodalan Kota Baubau. Suatu kegiatan dikatakan efisien apabila dikerjakan dengan benar dan sesuai dengan prosedur, sedangkan efektif bila kegiatan bila kegiatan tersebut dilaksanakan dengan benar dan dapat memberikan hasil yang bermanfaat

2) Faktor Penghambat Efektifitas Pelayanan Penerbitan Izin Usaha Pada Badan Pelayanan Perizinan Dan Penanaman Modal Kota Baubau.

Faktor-faktor yang meng-hambat dari efektifitas pelayanan penerbitan izin usaha Pada Badan Pelayanan Perizinan dan Penanaman Modal Kota Baubau yaitu; faktor waktu, factor biaya dan persyaratan dalam pelayanan perizinan disisi lain Pelayanan perizinan dilakukan sebagai upaya pemenuhan kebutuhan masyarakat, misalnya upaya instansi yang berwenang dalam memberikan jaminan kepastian hukum atas usaha yang dimiliki sehingga dapat menjamin segala aktivitas. 


\section{SIMPULAN}

Berdasarkan hasil pembahasan dapat di generalisasikan beberapa kesimpulan yang dapat diambil dalam penelitian ini antara lain: (1). Pelayanan penerbitan Izin Usaha Pada Badan Pelayanan Perizinan dan Penanaman Modal Kota Baubau dikatakan efektif karena tujuan atau sasaran yang dikehendaki dapat tercapai sesuai dengan rencana semula dan menimbulkan efek yang diharapkan oleh masyarakat. (2) Faktor-faktor yang menghambat efektifitas pelayanan penerbitan izin usaha Pada Badan Pelayanan Perizinan dan Penanaman Modal Kota Baubau yaitu : faktor waktu, faktorbiaya dan persyaratan dalam pelayanan perizinan.

Sebagai upaya meningkatkan Standar pelayanan sesuai dengan tuntutan Reformasi Birokrasi tentang pelayanan. Factor biaya pelayanan administrasi yang free atau tidak dikenakan biaya pada Badan Pelayanan Perizinan dan Penanaman Modal Kota Baubau sebaiknya dilakukan secara transparansi kepada seluruh masyarakat, dengan beberapa cara antara lain melalui papan informasi dan atau media online. Dari segi peningkatan kesadaran masyarakat untuk ikut berpartisipasi dalam mendaftarkan usaha yang dimiliki, hendaknya sering dilakukan sosialisasi dan publikasi tentang pendaftaran untuk menerbitkan izin demi meningkatkan efektifitas dan kualitas pelayanan. Meningkatkan pengawasan terhadap petugas pelayanan. Hal ini, dapat dilakukan melalui pemberian penghargaan yang senilai denganprestasi yang dilakukan aparat dalam memberikan pelayanan dan memberikan sanksi yang sebanding dengan perbuatan yang dilakukan aparat jika membuat kesalahan sehingga masalah yang menjadi penghambat dalam memberikan pelayanan dapat dihindari atau diperbaiki. Sebagai upaya dari proses transparansi dimaksud adalah penggunaan Kotak Saran publik dioptimalkan dalam proses peningkatkan partisipasi masyarakat pengguna jasa untuk memberikan kritik, saran atau pendapat atau proses pemberian pelayanan oleh aparat untuk meningkatkan control public demi tercapainya akuntabilitas pelayanan publik.

\section{E. DAFTAR PUSTAKA}

\section{Buku :}

C.S.T. Kansil dan Christine S.T. Kansil, 2005, Sistem Pemerintahan Indonesia, Cetakan Ke Dua. PT. Bumi Aksara, Jakarta.

Gaspersz, V.1997, Manajemen Kualitas Dalam Industri Jasa, Gramedia PustakaUtama : Jakarta.

Georpolous dan Tannenbaum, 1985, Efektivitas Organisasi, Alumni Bandung : Bandung.

Kurniawan, Agung, 2005, Transformasi Pelayanan Publik, Alumni Bandung : Bandung.

\section{PeraturanPerundang-Undangan}

Depdagri,2004, Modul Pengembangan Pelayanan Terpadu Satu Atap.

Keputusan Menteri Pemberdayagunaan Aparatur Negara No. 63tahun 2003 tentang Pedoman Umum Penyelenggaraan Pelayanan Publik 
Peraturan DaerahKota BaubauNo. 23

Tahun 2003 tentang Retribusi Izin

Industri, Perdagangan dan

Pergudangan.

Peraturan Daerah Kota Baubau No. 9

Tahun 2013 Tentang Surat Izin

Usaha Perdagangan Kota Baubau

Peraturan Menteri Perdagangan Nomor : 36 / M-DAG / PER / 9 / 2007 tentang Penerbitan Surat Izin Usaha Perdagangan sebagaimana telah diubah dengan Peraturan Menteri Perdagangan Nomor : 39 / M-DAG / PER / 12 / 2011.

Peraturan Pemerintah No.8 Tahun 2003 Tentang Pedoman Organisasi Perangkat Daerah.

Undang-Undang Nomor 20 Tahun 2008 Tentang Izin Usaha Mikro, Kecil dan Menengah (Lembar Negara Republik Indonesia Tahun 2008 Nomor 93) 